Check for updates

Cite this: RSC Adv., 2017, 7, 18311

\section{Synthesis and antimicrobial evaluation of promising 7-arylamino-5,8-dioxo-5,8-dihydroisoquinoline-4- carboxylates and their halogenated amino compounds for treating Gram-negative bacterial infections $\uparrow$}

\begin{abstract}
Juliana S. Novais, ${ }^{a}$ Vinicius R. Campos, ${ }^{b}$ Ana Carolina J. A. Silva, ${ }^{a}$ Maria C. B. V. de Souza, ${ }^{b}$ Vitor F. Ferreira, ${ }^{b}$ Vitor G. L. Keller, ${ }^{b}$ Matheus O. Ferreira, ${ }^{b}$ Flaviana R. F. Dias, ${ }^{b}$ Maíra I. Vitorino, ${ }^{a}$ Plínio C. Sathler, ${ }^{c}$ Marcos V. Santana, ${ }^{a}$ Jackson A. L. C. Resende, de Helena C. Castro a and Anna C. Cunha (D) *b

Pathogenic bacteria may cause serious infections, such as pneumonia, which can be fatal especially to immunosuppressed individuals. Hospitalized patients are particularly susceptible to antibiotic-resistant infections, which are worsened when caused by resistant Gram-negative pathogens due to there being few therapeutic options available. Thus, this work describes the synthesis and in vitro antimicrobial profile of 7-arylamino-5,8-dioxo-5,8-dihydroisoquinoline-4-carboxylates and their halogenated aminoquinones against Gram-positive and Gram-negative bacteria. Interestingly, these bioactive substances have shown promising activity against Gram-negative pathogenic strains. Among these derivatives, two non-halogenated amino compounds exhibited promising MIC and MBC values (MIC = MBC $=1-2 \mu \mathrm{g} \mathrm{mL}^{-1}$ ) against Escherichia coli ATCC 25922 and Pseudomonas aeruginosa ATCC 27853, two Gram-negative strains of clinical importance. In addition, mono- and di-brominated aminoquinones were also effective in preventing the growth of $E$. coli $\left(\mathrm{MIC}=\mathrm{MBC}=2-4 \mu \mathrm{g} \mathrm{mL}^{-1}\right)$. The in vitro hemocompatibility evaluation showed a low toxicity profile for the active aminoquinones in hemolysis assays. These results suggest that these substances have potential for exploring the design of new antimicrobial prototypes against Gram-negative bacteria.
\end{abstract}

Received 19th January 2017 Accepted 22nd February 2017

DOI: $10.1039 / \mathrm{c} 7 \mathrm{ra00825b}$

rsc.li/rsc-advances
Center for Disease Control and Prevention (CDC) has revealed that about 2 million patients in the United States (US) develop bacterial infections each year and 23000 deaths are directly related to bacterial infections. ${ }^{3}$

Based on these facts and due to the high degree of resistance of Gram-negative bacteria with the development of multidrugresistant (MDR - resistant to three or more classes of antimicrobials) and extensively drug-resistant (XDR - resistant to one or two classes of antimicrobials) strains, and the threatening risk of the development of pan-drug resistant (PDR - resistant to all classes of antimicrobials) strains, researchers have paid particular attention to the infection rate caused by this group., ${ }^{\mathbf{4} 5}$ Usually, Gram-negative bacteria are commonly associated with intra-abdominal infections (IAIs), bacteremia, ventilatorassociated pneumonia (VAP) and urinary tract infections (UTIs). The main pathogens involved in these infections are Escherichia coli, Klebsiella pneumoniae and Pseudomonas aeruginosa. Together, these species account for $70 \%$ of all Gramnegative bacteria causing health care associated infections in the US. ${ }^{6}$ 
These pathogens present resistance mechanisms that involve: (a) the expression of antibiotic-inactivating enzymes, such as carbapenemases, that usually confer resistance to $\beta$ lactams, ${ }^{7}$ and (b) non-enzymatic mechanisms, such as low permeability of the outer membrane and the presence of an efficient efflux system. ${ }^{8}$ The most severe clinical cases of infections caused by Gram-negative pathogens are often associated with health care acquired infections caused by extendedspectrum $\beta$-lactamase (ESBL) producing Enterobacteriaceae (e.g. E. coli), carbapenem-resistant Enterobacteriaceae (CRE) (e.g. K. pneumoniae), MDR Acinetobacter baumannii and MDR $P$. aeruginosa. ${ }^{9}$

In nosocomial infections, an important factor for the pathogenicity and persistence potential of Gram-negative bacteria is their ability to form a biofilm..$^{10}$ Bacteria that produce biofilms become more resistant to antibiotics than those in planktonic form as the biofilm acts as a physical barrier. ${ }^{11} P$. aeruginos $a$ and $E$. coli are the most common Gram-negative bacteria able to form biofilms in medical devices. ${ }^{12,13} P$. aeruginosa is also capable of forming biofilms in the lungs of cystic fibrosis patients, ${ }^{14}$ whereas $E$. coli is frequently associated with urinary catheter-related infections. ${ }^{15}$

All of these issues compromise the current strategies for the treatment of infections caused by Gram-negative bacteria, especially in view of the few therapeutic alternatives presently available. ${ }^{16}$ There are few antibacterial agents on the market, and combining antimicrobials, such as ceftolozane-tazobactam, is the current option for treating infections caused by resistant strains. The ceftolozane-tazobactam combination is effective against resistant Gram-negative bacteria such as $P$. aeruginosa and Enterobacteriaceae, including extended-spectrum $\beta$-lactamase (ESBL) producers. ${ }^{17}$ Meanwhile, ceftazidime, a broadspectrum cephalosporin, and avibactam, a $\beta$-lactamase inhibitor, are combined to treat resistant infections caused by ESBL and Klebsiella pneumoniae carbapenemase (KPC). ${ }^{18}$

Based on this scenario and considering the prevalence of infections caused by Gram-negative pathogens resistant to many or all antibacterial agents available, the discovery of new agents with potent activity against these strains is urgently required. ${ }^{19,20}$

Naturally occurring quinones are well-known as clinically useful drugs for treating cancer. ${ }^{21}$ Although most of the quinone derivatives show a potential cytotoxic profile against a number of cancer cell lines, ${ }^{22}$ they are still associated with other pharmacological activities, such as antibacterial, ${ }^{23}$ antifungal, ${ }^{24}$ antiviral, ${ }^{25}$ anti-inflammatory, ${ }^{26}$ and antimalarial. ${ }^{27}$

The literature about the rational design of antimicrobials describes several aminoquinone compounds ${ }^{28,29}(1-6)$ and halo1,4-naphtoquinone derivatives ${ }^{30}(7-8)$ with promising inhibitory effects against pathogenic bacteria (Fig. 1).

According to the literature, quinones may present different antimicrobial mechanisms. ${ }^{31,32}$ These substances may act through redox reactions producing reactive oxygen species (ROS), which can lead to cellular damage, oxidative stress and DNA damage. ${ }^{31}$ Quinone compounds are also able to inhibit DNA topoisomerase, an enzyme that catalyzes changes in DNA topology and is essential for bacterial replication..$^{32}$ Another mechanism involves inhibition of bacterial cell growth via a competitive electron transport

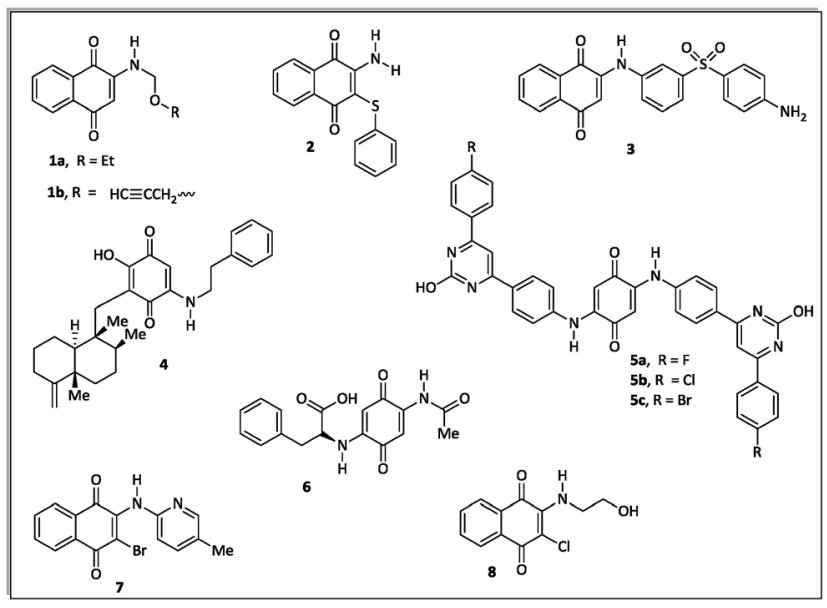

Fig. 1 Examples of quinone derivatives as antibacterial agents.

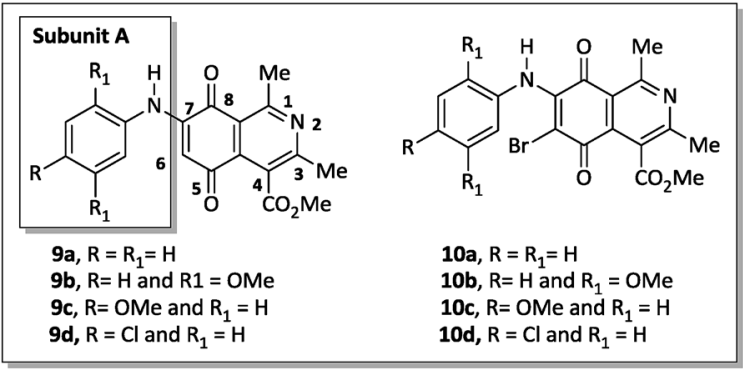

Fig. 2 Two homologous series of aminoquinone compounds, 9a$\mathrm{d}$ and $10 \mathrm{a}-\mathrm{d}$, which are structurally related to the reported fungicidal agents $10 c-d$ (see ref. 34).

process with interference of endogenous vitamin $\mathrm{K}$ or ubiquinone in the electron transfer chain. ${ }^{33}$

Recently Ryu, Song and Hong ${ }^{34}$ described 7-arylamino-5,8dioxo-5,8-dihydroisoquinoline-4-carboxylates as antifungal agents with similar or better profiles than fluconazole, a current therapeutic drug. Interestingly, these authors suggested that the inhibition of the fungal respiratory electron-transfer pathway was a feasible mechanism for active aminoquinone derivatives. Since this pathway is also present in Gram-negative and Gram-positive bacteria, ${ }^{35}$ in this article we report the synthesis of two homologous series of 7-arylamino-5,8-dioxo5,8-dihydroisoquinoline-4-carboxylates (9a-d and 10a-b), structurally related to the fungicidal agents 10c-d (Fig. 2), ${ }^{34}$ and tested them against bacterial strains of clinical importance.

In this work, we also analyzed their mechanism of action (bactericidal and/or bacteriostatic), the hemocompatibility profile and the contribution of different substituents on the phenylamino ring (9a-d), also including the bromo group at the C-6 carbon of the aza-quinone nucleus (10a-d).

\section{Results and discussion}

\subsection{Chemistry}

The 7-arylamino-5,8-dioxo-5,8-dihydroisoquinoline-4-carboxylates 9a-d were prepared using the synthetic sequence illustrated in 
Scheme 1 . The reaction between 2,5-dihydroxyacetophenone (11) and methyl 3-aminocrotonate (12) afforded methyl 5,8-dihydroxy1,3-dimethylisoquinoline-4-carboxylate (13), which was subjected to oxidation with $\mathrm{MnO}_{2}$ to furnish isoquinoline-5,8-dione 14 in $80 \%$ yield. $^{36}$

Aromatic amines 15a-d were transformed into the corresponding amino compounds 9a-d (Scheme 1) by ultrasoundaccelerated Michel addition of anilines to electrophilic quinone compound 14, under cerium catalysis, according to the procedure described in the literature ${ }^{34,36}$ with minor modifications.

The regioselective introduction of aniline substituents at the C-7 position of $\mathbf{1 4}$ was confirmed based on the 2D HMBC spectrum of the aminoquinone derivative 9d. For example, the proton from the $\mathrm{N}-\mathrm{H}$ bond $(7.67 \mathrm{ppm})$ showed long-range correlations $\left({ }^{3} J_{\mathrm{CH}}\right)$ with the carbon resonance for C-6 (102.8 ppm), C-2'/C-6' (124.6 ppm) and C-8 (181.6 ppm). This latter carbon showed correlation with the hydrogen H-6 (6.28 ppm). The observed regioselectivity for products $\mathbf{9 a - d}$ is in agreement with that reported by Ryu, Song and Hong. ${ }^{34}$ The carbonyl carbons C- 5 and C- 8 were differentiated based on the resonance effect caused by the presence of the amino group bonded at the C-7 position of the quinone-5,8-dione moiety of 9a-d, which stabilizes the C-5 carbonyl carbon making it less electrophilic (Fig. 3).

The reaction of compounds $\mathbf{9 a - d}$ with $N$-bromosuccinimide (NBS) led to halogenated derivatives 10a-d in poor yields after purification by silica gel column chromatography.

An alternative to the preparation of substances 10a-d consisted of the bromination reaction of $\mathbf{1 4}$ with molecular

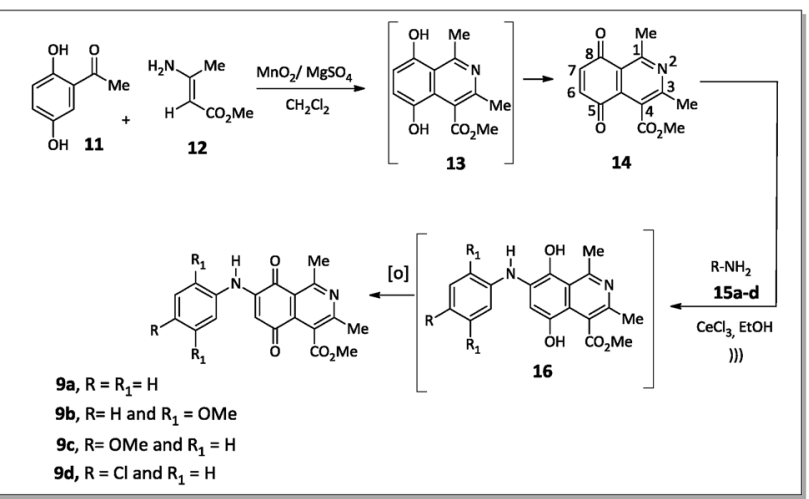

Scheme 1 Synthesis of aminoquinones $9 a-d$.

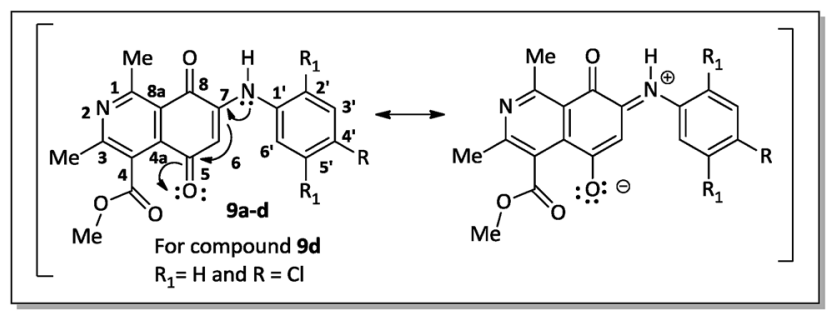

Fig. 3 Canonic structures of compounds $9 a-d$. bromine in a buffer solution of sodium acetate in glacial acetic acid, as shown in Scheme 2. This reaction afforded a mixture of di-brominated and tri-brominated compounds (17 and 18, respectively).

Compounds 17 and 18 were not isolated due to further degradation during chromatographic processing. For this reason, the crude product, which essentially consists of two major compounds, 17 and 18, was then submitted to nucleophilic substitution reaction with arylamines 15a-d, furnishing a mixture of the corresponding aminoquinone compounds 10ad and 19a-d (Scheme 3).

The X-ray crystallographic analysis of the amino compounds 10d and 19d (Fig. 4) allowed the molecular structures of 17 and 18 to be confirmed (Scheme 2).

All compounds, except 19a and 19b, were isolated as pure materials by silica gel column chromatography using chloroform/acetone $(9.5: 0.5)$ as an eluent mixture. The structures of the novel aminoquinone derivatives 9d, 10a-b and 19cd were confirmed by spectral data, including one- and twodimensional ${ }^{1} \mathrm{H}$ and ${ }^{13} \mathrm{C}$ NMR spectra $\left[{ }^{1} \mathrm{H},{ }^{13} \mathrm{C}-\mathrm{APT}\right.$, COSY- ${ }^{1} \mathrm{H}$ $\times{ }^{1} \mathrm{H}, \mathrm{HSQC}$ and HMBC], IR and mass analysis.

\subsection{Biological assay}

Initially, the antibacterial profile of the aza-quinone derivatives 9a-d, 10a-d, 14 and 19c-d was evaluated in vitro by measuring the inhibition zone against Gram-positive (Enterococcus faecalis ATCC 29212, Staphylococcus aureus ATCC 25923, Staphylococcus epidermidis ATCC 12228, and Staphylococcus simulans ATCC 27851) and Gram-negative bacteria (Enterobacter cloaceae ATCC 23355, Serratia marcescens ATCC 14756, Escherichia coli ATCC 25922, Proteus mirabilis ATCC 15290, Klebsiella pneumoniae ATCC 4352 and Pseudomonas aeruginosa ATCC 27853).

The disk diffusion data showed an inhibition zone (8-18 $\mathrm{mm}$ ) for these compounds with different patterns. Only compounds 9c and 9d were active against both Gram-positive (S. aureus ATCC 25923, S. epidermidis ATCC 12228 and S.

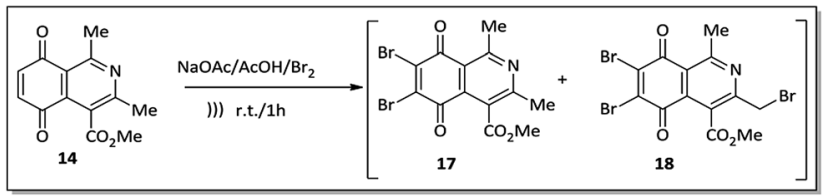

Scheme 2 Preparation of brominated compounds 17 and 18

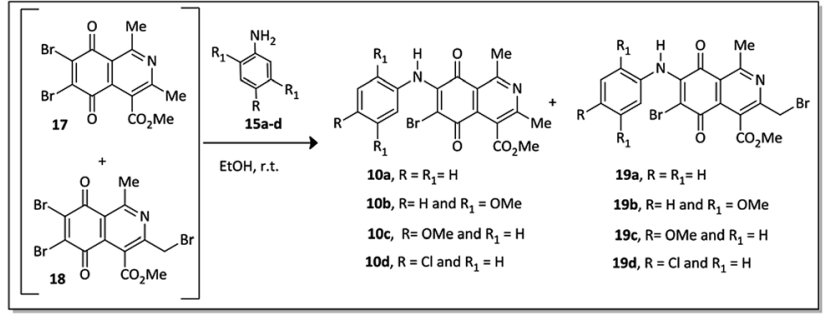

Scheme 3 Preparation of quinone derivatives $10 a-d$ and $19 a-d$ 


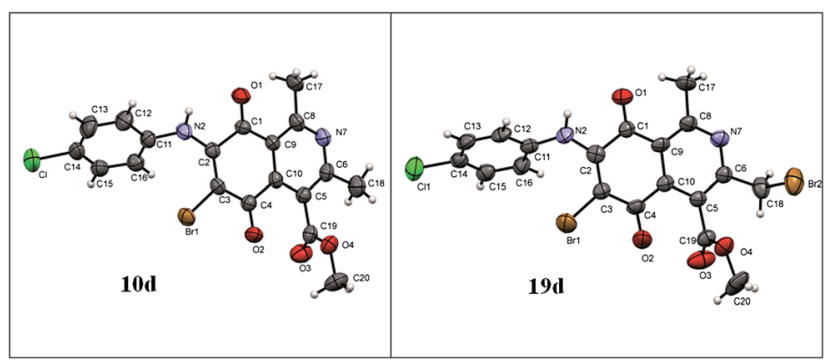

Fig. 4 Asymmetric unit representation of quinone derivatives $10 \mathrm{~d}$ and $19 \mathrm{~d}$ (ellipsoids at the $50 \%$ probability level).

simulans ATCC 27851) and Gram-negative (E. coli ATCC 25922 and $P$. aeruginosa ATCC 27853) bacteria (Table 1), suggesting that the substitution pattern on the aniline ring is a fundamental requirement for the antimicrobial activity.

Differently, compound 10d was effective against $S$. aureus ATCC 25923 and S. simulans ATCC 27851, whereas the related brominated compounds 10a and 10c showed antimicrobial effects against Gram-negative strains (E. coli ATCC 25922 and $P$. aeruginosa ATCC 27853) (Table 1). The derivative 10b was active against $S$. simulans ATCC 27851, E. coli ATCC 25922 and $P$. aeruginosa ATCC 27853.

The selectivity profile of the halogen compounds $10 \mathrm{a}$ and $10 \mathrm{c}$ was not observed for the non-brominated analogues 9a and 9c, indicating the importance of this type of substituent for the antibacterial activity.

Isoquinoline-5,8-dione (14) exhibited broad spectrum activity (14-25 mm) against Gram-positive and Gram-negative strains. These results showed the importance of the quinonoid ring for antibacterial activity. ${ }^{37}$

19c, a dibromo analogue of compound 10c, showed no antimicrobial activity, which suggested that the introduction of the second bromine at the benzylic position was responsible for the absence of activity. On the other hand, the dibromo compound 19d, containing a chlorine substituent on the benzene ring of the aniline group, showed antimicrobial activity against S. simulans ATCC 27851, E. coli ATCC 25922 and $P$. aeruginosa ATCC 27853. This fact is in agreement with previous results that indicate the chlorine atom substituent as a modulating parameter for the antibacterial profile. ${ }^{38}$

After the disk diffusion analyses, the active compounds were analyzed using an MIC assay to determine the lowest concentration capable of inhibiting visible bacterial growth. The MIC values listed in Table 2 revealed that the non-brominated compounds $\mathbf{9 c - d}$ had promising antimicrobial profiles against Gram-negative strains (E. coli ATCC25922 and $P$. aeruginosa ATCC27853) with MICs (1-2 $\left.\mu \mathrm{g} \mathrm{mL}^{-1}\right)$ close to that observed for ciprofloxacin, an antibacterial currently in use, and within CLSI values $\left(0.05-256 \mu \mathrm{g} \mathrm{mL}^{-1}\right)$ (Table 2$)$.

The analysis of the antibacterial mechanism of these derivatives showed significant minimal bactericidal concentration (MBC) values (Table 3). The MBC is complementary to the MIC, since whereas MIC demonstrates the lowest level of antimicrobial necessary to inhibit growth, MBC represents the lowest level of antimicrobial agent that results in microbial death. According to the ratio of $\mathrm{MBC} / \mathrm{MIC}$, it is possible to identify a compound's antibacterial profile (bacteriostatic and/or bactericidal). A ratio of $\mathrm{MBC} / \mathrm{MIC} \leq 2$ indicates bactericidal activity, whereas a ratio of $\mathrm{MBC} / \mathrm{MIC} \geq 4$ defines a bacteriostatic effect. ${ }^{39}$

Interestingly, the MBC and MIC values of the active derivatives 9c-d, 10c, 14 and 19d were identical against $E$. coli ATCC 25922 and $P$. aeruginosa ATCC 27853. This suggests that these compounds can be classified as bactericidal agents against Gram-negative bacteria, which is a more interesting profile.

Table 1 Antimicrobial evaluation of quinone derivatives 9a-d, 10a-d, 14 and 19c-d against Gram-positive and Gram-negative bacterial strains of clinical importance using a disc diffusion test ${ }^{a}$

\begin{tabular}{|c|c|c|c|c|c|}
\hline \multirow{4}{*}{ Compound } & \multicolumn{5}{|c|}{ Inhibition zone (mm) } \\
\hline & \multicolumn{3}{|l|}{ Gram-positive } & \multicolumn{2}{|c|}{ Gram-negative } \\
\hline & $\begin{array}{l}\text { S. aureus } \\
\text { ATCC } 25923\end{array}$ & S. epidermidis & $\begin{array}{l}\text { S. simulans } \\
\text { ATCC } 27851\end{array}$ & $\begin{array}{l}\text { E. coli } \\
\text { ATCC } 25922\end{array}$ & $\begin{array}{l}\text { P. aeruginosa } \\
\text { ATCC } 27853\end{array}$ \\
\hline & & & & & \\
\hline 9a & 0 & 0 & 0 & 0 & 0 \\
\hline $9 b$ & 0 & 0 & 0 & 0 & 0 \\
\hline $9 c$ & 0 & $12 \pm 2$ & $11 \pm 1$ & $18 \pm 2$ & $15 \pm 1$ \\
\hline 9d & $9 \pm 2$ & $10 \pm 2$ & $10 \pm 2$ & $15 \pm 1$ & $12 \pm 2$ \\
\hline 10a & 0 & 0 & 0 & 0 & $9 \pm 2$ \\
\hline 10b & 0 & 0 & $10 \pm 3$ & $8 \pm 1$ & $9 \pm 2$ \\
\hline $10 \mathrm{c}$ & 0 & 0 & 0 & $8 \pm 2$ & 0 \\
\hline 10d & $12 \pm 1$ & 0 & $11 \pm 2$ & 0 & 0 \\
\hline 14 & $15 \pm 1$ & $14 \pm 1$ & $16 \pm 2$ & $25 \pm 1$ & $23 \pm 1$ \\
\hline 19c & 0 & 0 & 0 & 0 & 0 \\
\hline 19d & 0 & 0 & $8 \pm 2$ & $9 \pm 2$ & $10 \pm 2$ \\
\hline Cip & - & - & - & $34 \pm 2$ & $39 \pm 3$ \\
\hline Van & $14 \pm 2$ & $15 \pm 2$ & $12 \pm 2$ & - & - \\
\hline DMSO & 0 & 0 & 0 & 0 & 0 \\
\hline
\end{tabular}

${ }^{a} \mathrm{Cip}=$ ciprofloxacin and Van = vancomycin (positive controls); DMSO = dimethyl sulphoxide (negative control). 
Table 2 Comparison of the minimum inhibitory concentrations (MICs) of quinone compounds 9a-d, 10a-d, 14 and 19c-d against Grampositive and Gram-negative bacteriac

\begin{tabular}{|c|c|c|c|c|c|}
\hline \multirow[b]{2}{*}{ Compound } & \multicolumn{5}{|c|}{$\operatorname{MIC}\left(\mu \mathrm{g} \mathrm{mL}^{-1}\right)$} \\
\hline & $\begin{array}{l}\text { S. aureus } \\
\text { ATCC } 25923\end{array}$ & $\begin{array}{l}\text { S. epidermidis } \\
\text { ATCC } 12228\end{array}$ & $\begin{array}{l}\text { S. simulans } \\
\text { ATCC } 27851\end{array}$ & $\begin{array}{l}\text { E. coli } \\
\text { ATCC } 25922\end{array}$ & $\begin{array}{l}\text { P. aeruginosa } \\
\text { ATCC } 27853\end{array}$ \\
\hline $9 a$ & ND & ND & ND & ND & ND \\
\hline $9 b$ & ND & ND & ND & ND & ND \\
\hline $9 c$ & ND & ND & ND & 1 & 2 \\
\hline $10 b$ & ND & ND & 64 & 128 & 128 \\
\hline $10 \mathrm{c}$ & ND & ND & ND & 4 & ND \\
\hline $10 \mathrm{~d}$ & 32 & ND & 16 & ND & ND \\
\hline 14 & ND & 128 & 128 & 4 & 8 \\
\hline $19 c$ & ND & ND & ND & ND & ND \\
\hline 19d & ND & ND & 32 & 2 & 16 \\
\hline
\end{tabular}

${ }^{a}$ Ciprofloxacin: positive control used for Gram-negative strains. ${ }^{b}$ Vancomycin: positive control used for Gram-positive strains. ${ }^{c}$ ND: no detected activity at $256 \mu \mathrm{g} \mathrm{mL}{ }^{-1}$.

Table 3 Analysis of the mechanism of action (bactericidal and/or bacteriostatic) through minimal bactericidal concentration (MBC) and MBC/ MIC ratio determination of the active compounds $9 c-d, 10 a-d, 14$ and $19 d^{a}$

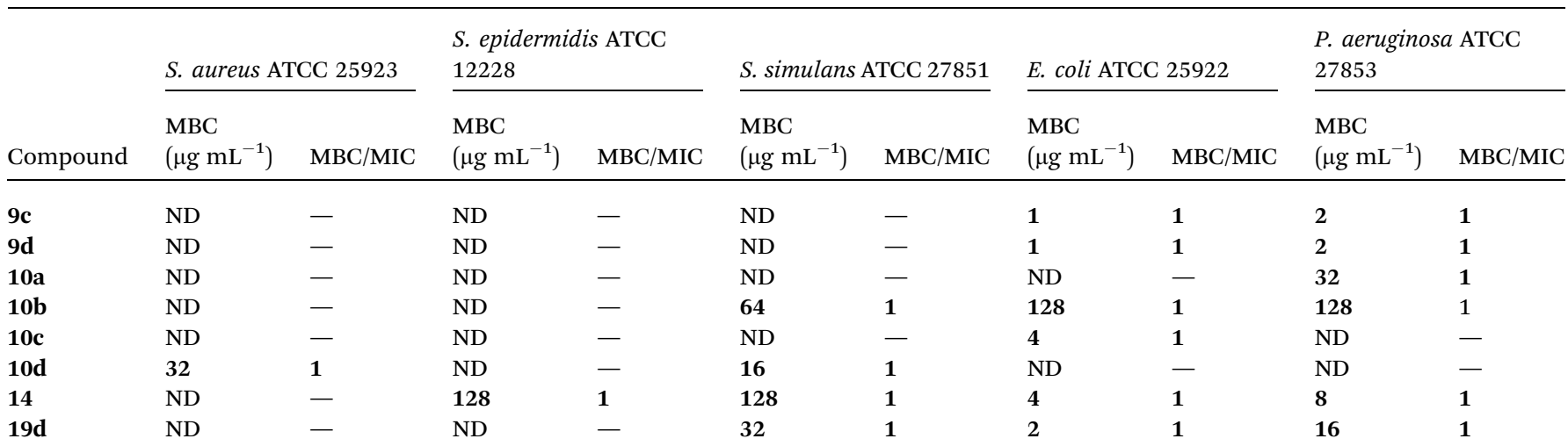

${ }^{a} \mathrm{ND}$ : no detected activity at $256 \mu \mathrm{g} \mathrm{mL}^{-1}$. A ratio of $\mathrm{MBC} / \mathrm{MIC} \leq 2$ indicates bactericidal activity, whereas a ratio of $\mathrm{MBC} / \mathrm{MIC} \geq 4$ defines a bacteriostatic effect.

It is known that Gram-negative bacteria are more resistant to antimicrobial agents than Gram-positive bacteria due to their different morphological features. These bacteria present a more complex biological barrier that avoids the penetration of different antibiotics, whereas their periplasmic space has proteins and enzymes able to break down foreign molecules. ${ }^{40}$ Therefore, the identification of active molecules/lead compounds against Gram-negative bacteria, such as those identified in this work, is extremely relevant for designing new antimicrobials for medical use. This is even more important in the case of difficult-to-treat infections, like those involving resistant microorganisms. Thus bactericidal compounds that are able to kill microorganisms lead to a faster end of the bacterial infection, also reducing the rates of re-incidence and resistance. ${ }^{41}$

Most of the quinone analogues showed high MIC values $\left(>256 \mu \mathrm{g} \mathrm{mL} \mathrm{m}^{-1}\right.$ ) against Gram-positive strains, suggesting a selective mechanism for those effective against Gram-negative strains (e.g. 9c-d). Among the mono-brominated compounds tested, the derivative $\mathbf{1 0 b}$ containing methoxy groups at the ortho- and para-positions of the aniline group exhibited the highest MIC $\left(128 \mu \mathrm{g} \mathrm{mL}^{-1}\right)$, whereas monomethoxylated related compound 10c showed 32 times lower MIC $\left(4 \mu \mathrm{g} \mathrm{mL}{ }^{-1}\right)$ and MBC $\left(4 \mu \mathrm{g} \mathrm{mL}^{-1}\right)$ against E. coli ATCC 25922 (Table 2). The comparison between non-brominated compound 9c and brominated compound 10c indicated the negative effect of the bromine atom, which reduced the antibacterial activity against Gram-negative bacteria at least four-fold (Table 2).

A selective antibacterial profile against Gram-negative strains was observed when comparing mono-10d and di-19d brominated compounds. Apparently, the second bromine atom had a great effect on the bacterial activity of 19d (Table 2). This molecule was more potent and selective against $E$. coli ATCC 25922 and P. aeruginosa ATCC 27853 than derivative 10d. 
Compound $\mathbf{1 4}$ is a synthetic intermediate that revealed broad-spectrum activity, detected in the disk diffusion test (Table 1). Interestingly, the results of the MIC assay showed better activity against Gram-negative strains $\left(4-8 \mu \mathrm{g} \mathrm{mL}{ }^{-1}\right)$, indicating that the isoquinoline-5,8-dione is an important medicinal moiety that can be modulated for targeting Gramnegative strains. Additionally, a Michael 1,4-addition type reaction between 14 and $p$-chloroaniline or $p$-methoxyaniline led to the formation of the corresponding compounds $\mathbf{9 c - d}$, which exhibited the best antibacterial activity among all of the molecules studied, with MIC values of $1.0 \mu \mathrm{g} \mathrm{mL}{ }^{-1}$ and $2.0 \mu \mathrm{g}$ $\mathrm{mL}^{-1}$ against E. coli ATCC 25922 and P. aeruginosa ATCC 27853.

Hemolysis tests on erythrocytes performed with compounds 9c-d, 10a-d, 14 and 19d showed that these quinone derivatives had no hemolytic effect after 3 hours of incubation (0.65-8.6\%) (Chart 1). Thus, these compounds can be identified as hemocompatible and non-cytotoxic to erythrocyte membranes, according to Fisher and co-workers (lysis rate $<10 \%) .{ }^{42}$

It is important to highlight that the aminoquinones $10 \mathrm{c}-$ d were recently described due to their antifungal effect against pathogenic fungi strains. ${ }^{34}$ The results from these studies showed that the substituted phenylamino group at the quinone nucleus plays an important role in the antifungal activity, similar to what we observed in the case of antibacterial activity. The authors $^{34}$ suggested that 5,8-dioxo-5,8-dihydroisoquinolines related to the compounds $\mathbf{1 0 c - d}$ can act as inhibitors of the cytochrome $b$ complex through the blockade of mitochondrial electron transport in fungi. Considering that this is a pathway also present in bacteria and that quinones and related analogs may act as redox-active molecules, this is also a possible mechanism of action for the active compounds 9c-d, 10a-d, 14 and 19d. The structures of these substances are in agreement with an electron-acceptor profile, which corroborates this hypothesis. The use of orthogonal assays to further explore quinone derivatives as inhibitors of the mitochondrial respiratory chain enzyme cytochrome $\mathrm{b}$ will be extremely useful, and will rationally assist the selection of these molecules for further in vivo and in vitro assays. ${ }^{43-45}$

According to the World Health Organization (WHO), the incidence of fungal and bacterial infections is a serious problem

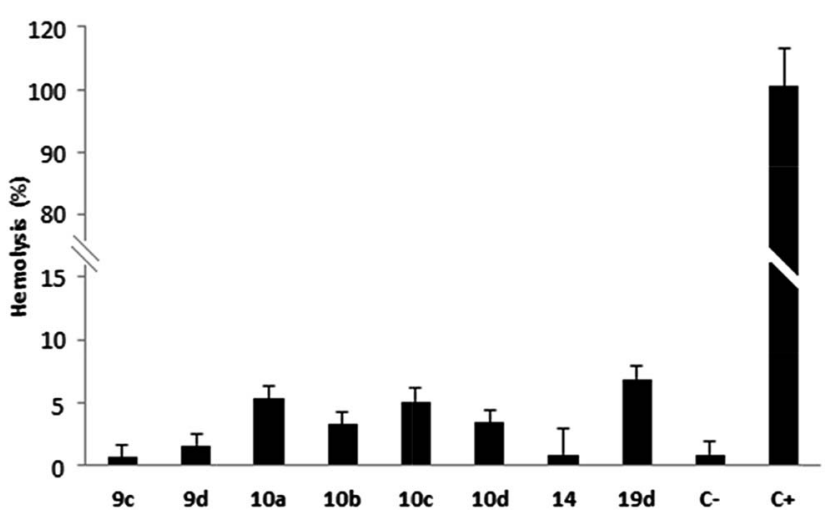

Chart 1 Hemolytic profile through hemolysis assay. Values below $10 \%$ are considered non-hemolytic. 1\% DMSO (C-) and Triton X-100 (C+) are the negative and positive controls, respectively. worldwide, especially in immunosuppressed individuals such as those infected with human immunodeficiency virus (HIV). ${ }^{\mathbf{4 6}}$ This situation has worsened due to the increase of multi-drug resistant pathogen strains (e.g. fungi, bacteria and viruses), which require more and new treatment options. ${ }^{47,48}$ Therefore, the discovery of molecules with antifungal and antibacterial profiles such as 10c-d, as well as exploring the dual mechanism in new antibacterial derivatives such as 9c-d for treating immunosuppressed individuals such as those with HIV or cancer is interesting.

\section{Conclusions}

In summary, we have reported the efficient synthesis and in vitro antimicrobial activity of 7-arylamino-5,8-dioxo-5,8dihydroisoquinoline-4-carboxylates $\mathbf{9 a - d}$ and their halogenated amino derivatives $\mathbf{1 0 a}-\mathbf{d}$ and 19c-d. Among these aminoquinone compounds, the non-halogenated substances 9cd showed promising antimicrobial profiles with MIC and MBC values in the range of 1.0 to $2.0 \mu \mathrm{g} \mathrm{mL}^{-1}$ against Gram-negative strains (E. coli ATCC25922 and P. aeruginosa ATCC27853). In addition, the brominated compounds 10c and 19d and their synthetic precursor 14 showed selective antimicrobial activity against $E$. coli ATCC25922, with both MIC and MBC values in the range of 2.0 to $4.0 \mu \mathrm{g} \mathrm{mL} \mathrm{m}^{-1}$.

Our results suggest that the antibacterial effect with a bactericidal profile of these compounds against Gramnegative bacteria is of importance, since the emergence of resistant strains continues and this type of bacteria is of great concern. The derivatives 9c-d, 10c, 14 and 19d had no hemolysis profile when tested on erythrocyte cultures, and constitute promising prototypes for further analysis on antimicrobial therapy.

\section{Experimental}

\subsection{In vitro biological assay}

Bacterial strains. Bacterial strains were obtained from the American Type Culture Collection (ATCC) including Grampositive (Enterococcus faecalis ATCC 29212, Staphylococcus aureus ATCC 25923, S. epidermidis ATCC 12228, and $S$. simulans ATCC 27851) and Gram-negative (Enterobacter cloaceae ATCC 23355, Serratia marcescens ATCC 14756, Escherichia coli ATCC 25922, Proteus mirabilis ATCC 15290, Klebsiella pneumoniae ATCC 4352 and Pseudomonas aeruginosa ATCC 27853) bacteria. All strains were maintained in $10 \%$ glycerol stocks and were stored at $-20{ }^{\circ} \mathrm{C}$ until use.

Disk diffusion method. Initially, the antibacterial profile of the isoquinoline derivatives was evaluated using the disk diffusion method based on Kirby-Bauer's description and according to the recommendations of the Clinical and Laboratory Standards Institute. ${ }^{49}$ Briefly, we prepared a bacterial suspension $\left(1.0 \times 10^{8}\right.$ colony-forming units $\left.\left(\mathrm{CFU} \mathrm{mL}{ }^{-1}\right)\right)$, which corresponded to McFarland standard 0.5. This suspension was inoculated on a Petri dish containing Müller Hinton agar (HIMEDIA) and after drying, paper disks (6 $\mathrm{mm}$ in diameter Laborclin ${ }^{\circledR}$ ) with $30 \mu \mathrm{g}$ per disk of derivative dissolved in $100 \%$ 
dimethyl sulfoxide (DMSO - Sigma-Aldrich) were applied onto them. After $24 \mathrm{~h}$ at $37^{\circ} \mathrm{C}$, the inhibition zone formed around the disks was measured in $\mathrm{mm}$. Vancomycin and ciprofloxacin were used as positive controls, whereas DMSO (100\%) was used as a negative control. The experiments were performed in triplicate.

Minimum inhibitory concentration (MIC) by the microdilution method. Active compounds detected by the disk diffusion assays were subjected to MIC analyses to determine the lowest concentration that inhibits bacterial growth. First, a three-fold derivative dilution (256-0.125 $\mu \mathrm{g} \mathrm{mL}^{-1}$ ) was prepared in a 96-well microplate, with a volume of $100 \mu \mathrm{L}$ in each well. The highest DMSO concentration used was $5 \%$ with no detectable effect on bacterial growth. Secondly, $100 \mu \mathrm{L}$ of bacterial inoculum containing $10^{6} \mathrm{CFU} \mathrm{mL}^{-1}$ was added. A negative control was prepared using the inoculum without derivative, whereas vancomycin and ciprofloxacin were used as positive controls. The microplates were incubated at $37^{\circ} \mathrm{C}$ for $24 \mathrm{~h}$ and the result was determined by visual reading of the lowest concentration with no detectable turbidity (growth). The experiments were performed in triplicate.

Minimal bactericidal concentration (MBC). The MBC value was determined by transferring the culture medium of each well with no visible growth $(10 \mu \mathrm{L})$ to agar plates. These plates were incubated for $24 \mathrm{~h}$ at $37{ }^{\circ} \mathrm{C}$ and the MBC was defined as the minimum concentration of derivative that showed $\geq 99.9 \%$ reduction of the original inoculum. The experiment was repeated at least three times. A colorimetric assay using resazurin was also performed and compared to the conventional plate method to reinforce the quantitative data. Briefly, $20 \mu \mathrm{L}$ of $0.01 \%$ resazurin (Sigma-Aldrich) was added into each well of the 96-well microtiter plates used for the MIC assay, after the previous incubation with the derivative, and re-incubated for 2 hours. The MBC was determined in the well treated with the lowest derivative concentration that did not change from blue to pink. $^{50}$ The ratio of $\mathrm{MBC} / \mathrm{MIC}$ was used to determine whether the mechanism of action of the derivatives was bactericidal $(\mathrm{MBC} / \mathrm{MIC}=1$ or 2$)$ or bacteriostatic $(\mathrm{MBC} / \mathrm{MIC}=4$ or 16$) .{ }^{51}$

Hemocompatibility - hemolysis assay. The experiment was conducted according to Sathler and collaborators (2014). ${ }^{52}$ Samples were obtained from healthy human subjects in compliance with laws and institutional guidelines, with the approval of the institutional ethics committee in humans research according to the decision 621196 approved in May 2014 with an expiration date of May 2018. The consent terms were presented to research participants and signed in all experiments involving humans. Erythrocytes were washed 3 times with PBS ( $\mathrm{pH} 7.4$ ) by centrifugation and suspended in the same buffer. All derivatives $\left(200 \mu \mathrm{g} \mathrm{mL}{ }^{-1}\right)$ were incubated with the erythrocyte suspension for $3 \mathrm{~h}$ at $37{ }^{\circ} \mathrm{C}$. The lysis of the erythrocytes and the release of hemoglobin was determined from the optical density of the supernatant at $540 \mathrm{~nm}$. The experiments were performed in triplicate and complete hemolysis (positive control) was determined by using $1 \%$ Triton $\mathrm{X}$ 100. Hemolysis less than $10 \%$ represented good hemocompatibility and non-toxicity against erythrocyte membranes, as described elsewhere. ${ }^{42,53,54}$

\subsection{Synthesis of 7-arylaminoisoquinolinequinone} derivatives 9a-d

Into a $50 \mathrm{~mL}$ round-bottom flask were added $245 \mathrm{mg}(1.0 \mathrm{mmol})$ of isoquinoline-5,8-dione (14), $2.0 \mathrm{mmol}$ of the required arylamine $15 \mathrm{a}-\mathrm{d}, 18.5 \mathrm{mg}(0.05 \mathrm{mmol})$ of $\mathrm{CeCl}_{3} \cdot 7 \mathrm{H}_{2} \mathrm{O}$ and $20 \mathrm{~mL}$ of anhydrous ethanol. The reaction mixture was stirred at room temperature for 5 hours. After removal of the solvent under reduced pressure, the aminoquinone derivatives $9 a-d$ were purified using a silica gel chromatographic column, using chloroform/acetone $(9.5: 0.5)$ as the eluent.

Methyl 7-(4-chlorophenyl)amino-1,3-dimethyl-5,8-dioxo-5,8dihydroisoquinoline-4-carboxylate (9d). The substance 9d was obtained as an orange solid, mp: $284-286{ }^{\circ} \mathrm{C}$, in $85 \%$ yield.

IR $\nu_{\max }\left(\mathrm{cm}^{-1} ; \mathrm{KBr}\right): 3300(\mathrm{~N}-\mathrm{H}), 1715$ and $1669(\mathrm{C}=\mathrm{O}), 1074$ and $1255(\mathrm{C}-\mathrm{O})$.

${ }^{1} \mathrm{H}$ NMR (500.00 MHz, $\left.\mathrm{CDCl}_{3}\right) \delta(\mathrm{ppm}): 2.61\left(\mathrm{~s}, 3 \mathrm{H}, \mathrm{CH}_{3}\right), 2.98$ $\left(\mathrm{s}, 3 \mathrm{H}, \mathrm{CH}_{3}\right), 4.00\left(\mathrm{~s}, 3 \mathrm{H}, \mathrm{OCH}_{3}\right), 6.28(\mathrm{~s}, 1 \mathrm{H}, \mathrm{H}-6), 7.19(\mathrm{~d}, 2 \mathrm{H}, J=$ $8.5 \mathrm{~Hz}, \mathrm{H}-2^{\prime}$ and $\left.\mathrm{H}-6^{\prime}\right), 7.39$ (d, $2 \mathrm{H}, J=8.5 \mathrm{~Hz}, \mathrm{H}-3^{\prime}$ and $\mathrm{H}-5^{\prime}$ ), 7.67 (s, $1 \mathrm{H}, \mathrm{N}-\mathrm{H})$.

${ }^{13} \mathrm{C} \mathrm{NMR}\left(125.0 \mathrm{MHz}, \mathrm{CDCl}_{3}\right) \delta(\mathrm{ppm}): 23.1\left(\mathrm{CH}_{3}\right), 26.2\left(\mathrm{CH}_{3}\right)$, $53.2\left(\mathrm{OCH}_{3}\right), 119.9(\mathrm{C}-8 \mathrm{a}), 124.2\left(\mathrm{C}-2^{\prime}\right.$ and $\left.\mathrm{C}-6^{\prime}\right), 125.3(\mathrm{C}-4)$, $130.1\left(\mathrm{C}-3^{\prime}\right.$ and $\left.\mathrm{C}-5^{\prime}\right), 131.8\left(\mathrm{C}-4^{\prime}\right), 135.6\left(\mathrm{C}-1^{\prime}\right), 137.7(\mathrm{C}-4 \mathrm{a})$, 102.8 (C-6), 145.3 (C-7), 161.2 (C-3), 161.5 (C-1), 169.1 (C-4b), 181.5 (C-5), $181.6(\mathrm{C}-8)$.

HRMS $[\mathrm{M}+\mathrm{H}]^{+}: m / z$ calcd for $\mathrm{C}_{19} \mathrm{H}_{15} \mathrm{~N}_{2} \mathrm{O}_{4}: 371.0799$; found: 371.0777 .

\subsection{Synthesis of 7-arylamino-6-bromo-isoquinolinequinone compounds 10a-d and dibrominated derivatives 19a-d}

Into a $50 \mathrm{~mL}$ round-bottom flask were added $245 \mathrm{mg}(1.0$ $\mathrm{mmol}$ ) of isoquinoline-5,8-dione (14), $660 \mathrm{mg}(8.0 \mathrm{mmol})$ of $\mathrm{NaOAc}$ and $8 \mathrm{~mL}$ of HOAc. The reaction mixture was stirred at room temperature for $10 \mathrm{~min}$ and then $0.1 \mathrm{~mL}$ of bromine was added to the reaction medium. The resulting mixture was kept in an ultrasonic water bath for 60 minutes. After this period, the reaction was quenched by addition of $200 \mathrm{~mL}$ of water and the crude residue consisting mainly of a mixture of di- and tri-brominated quinones, 17 and 18, respectively, was employed in the next reaction step without prior purification.

The products 17 and 18 (200 mg) and the appropriate arylamine $(0.15 \mathrm{mmol})$ were mixed together in EtOH $(20 \mathrm{~mL})$. The reaction mixture was stirred at room temperature for $60 \mathrm{~min}$. After removal of the solvent under reduced pressure, the monoand di-brominated compounds were purified by silica gel chromatography using chloroform : acetone $(9.5: 0.5)$ as the eluent.

Methyl 6-bromo-7-phenylamino-1,3-dimethyl-5,8-dioxo-5,8dihydroisoquinoline-4-carboxylate (10a). The substance 10a was obtained as a red solid, mp: $186-188{ }^{\circ} \mathrm{C}$, in $63 \%$ yield.

IR $\nu_{\max }\left(\mathrm{cm}^{-1} ; \mathrm{KBr}\right): 3258(\mathrm{~N}-\mathrm{H}), 1721$ and $1671(\mathrm{C}=\mathrm{O}), 1296$ and 1085 (C-O).

${ }^{1} \mathrm{H}$ NMR (500.00 MHz, $\left.\mathrm{CDCl}_{3}\right) \delta(\mathrm{ppm}): 2.97\left(\mathrm{~s}, 3 \mathrm{H}, \mathrm{CH}_{3}\right), 2.62$ $\left(\mathrm{s}, 3 \mathrm{H}, \mathrm{CH}_{3}\right), 4.03\left(\mathrm{~s}, 3 \mathrm{H}, \mathrm{OCH}_{3}\right), 7.09-7.11\left(\mathrm{~m}, 2 \mathrm{H}, \mathrm{H}-2^{\prime}\right.$ and $\mathrm{H}-$ $\left.6^{\prime}\right)$, 7.24-7.27 (m, $\left.1 \mathrm{H}, \mathrm{H}-4^{\prime}\right)$, 7.34-7.37 (m, 2H, $\mathrm{H}-3^{\prime}$ and $\mathrm{H}-5^{\prime}$ ), $7.98(\mathrm{~s}, 1 \mathrm{H}, \mathrm{N}-\mathrm{H})$. 
${ }^{13} \mathrm{C} \mathrm{NMR}\left(125.0 \mathrm{MHz}, \mathrm{CDCl}_{3}\right) \delta(\mathrm{ppm}): 22.7\left(\mathrm{CH}_{3}\right), 25.6\left(\mathrm{CH}_{3}\right)$, $53.4\left(\mathrm{OCH}_{3}\right), 119.6(\mathrm{C}-8 \mathrm{a}), 125.2\left(\mathrm{C}-2^{\prime}\right.$ and $\left.\mathrm{C}-6^{\prime}\right), 126.3(\mathrm{C}-4)$, $128.7\left(\mathrm{C}-3^{\prime}\right.$ and $\left.\mathrm{C}-5^{\prime}\right), 126.6\left(\mathrm{C}-4^{\prime}\right), 136.8\left(\mathrm{C}-1^{\prime}\right), 137.0(\mathrm{C}-4 \mathrm{a})$, 104.9 (C-6), 145.0 (C-7), 161.1 (C-3), 161.3 (C-1), 168.2 (C-4b), 175.5 (C-5), 179.5 (C-8).

HRMS $[\mathrm{M}+\mathrm{H}]^{+}: \mathrm{m} / z$ calcd for $\mathrm{C}_{19} \mathrm{H}_{15} \mathrm{BrN}_{2} \mathrm{O}_{4}:$ 415.0293; found: 415.0313 .

Methyl 6-bromo-7-(2,5-dimethoxyphenyl)amino-1,3-dimethyl5,8-dioxo-5,8-dihydroisoquinoline-4-carboxylate (10b). The substance $10 \mathrm{~b}$ was obtained as a red solid, mp: $138-140{ }^{\circ} \mathrm{C}$, in $52 \%$ yield.

IR $\nu_{\max }\left(\mathrm{cm}^{-1} ; \mathrm{KBr}\right): 3278(\mathrm{~N}-\mathrm{H}), 1727$ and $1677(\mathrm{C}=\mathrm{O}), 1316$ and $1157(\mathrm{C}-\mathrm{O})$.

${ }^{1} \mathrm{H}$ NMR $\left(500.00 \mathrm{MHz}, \mathrm{CDCl}_{3}\right) \delta(\mathrm{ppm}): 3.00\left(\mathrm{~s}, 3 \mathrm{H}, \mathrm{CH}_{3}\right), 2.70$ (s, $\left.3 \mathrm{H}, \mathrm{CH}_{3}\right), 3.78\left(\mathrm{~s}, 3 \mathrm{H}, \mathrm{Ph}-\mathrm{OCH}_{3}\right), 3.77$ (s, 3H, Ph- $\left.\mathrm{OCH}_{3}\right), 4.05$ $\left(\mathrm{s}, 3 \mathrm{H}, \mathrm{OCH}_{3}\right), 6.64$ (d, $\left.1 \mathrm{H}, J=2.9 \mathrm{~Hz}, \mathrm{H}-3^{\prime}\right), 6.77$ (dd, $1 \mathrm{H}, J=2.9$ and $\left.9.0 \mathrm{~Hz}, \mathrm{H}-4^{\prime}\right), 6.82\left(\mathrm{~d}, 1 \mathrm{H}, J=9.0 \mathrm{~Hz}, \mathrm{H}-6^{\prime}\right), 7.73(\mathrm{~s}, 1 \mathrm{H}, \mathrm{N}-\mathrm{H})$.

${ }^{13} \mathrm{C} \mathrm{NMR}\left(125.0 \mathrm{MHz}, \mathrm{CDCl}_{3}\right) \delta(\mathrm{ppm}): 21.8\left(\mathrm{CH}_{3}\right), 24.4\left(\mathrm{CH}_{3}\right)$, $53.7\left(\mathrm{OCH}_{3}\right), 55.8\left(\mathrm{Ph}-\mathrm{OCH}_{3}\right), 56.2\left(\mathrm{Ph}-\mathrm{OCH}_{3}\right), 120.5(\mathrm{C}-8 \mathrm{a})$, $146.7\left(\mathrm{C}-2^{\prime}\right), 111.6\left(\mathrm{C}-3^{\prime}\right), 111.9\left(\mathrm{C}-6^{\prime}\right), 112.3\left(\mathrm{C}-4^{\prime}\right), 153.2\left(\mathrm{C}-5^{\prime}\right)$, 126.6 (C-4), 126.5 (C-1'), 137.4 (C-4a), 105.0 (C-6), 145.9 (C-7), 160.2 (C-3), 160.3 (C-1), 167.7 (C-4b), 174.7 (C-5), 178.6 (C-8).

HRMS $[\mathrm{M}+\mathrm{H}]^{+}: \mathrm{m} / z$ calcd for $\mathrm{C}_{21} \mathrm{H}_{19} \mathrm{BrN}_{2} \mathrm{O}_{6}: 475.0505$; found: 475.0485 .

Methyl 6-bromo-7-(4-methoxyphenyl)amino-1,3-dimethyl5,8-dioxo-5,8-dihydroisoquinoline-4-carboxylate (10c). The substance 10c was obtained as a red solid, mp: $136-138{ }^{\circ} \mathrm{C}$, in $60 \%$ yield.

IR $\nu_{\max }\left(\mathrm{cm}^{-1} ; \mathrm{KBr}\right): 3303(\mathrm{~N}-\mathrm{H}), 1732$ and $1675(\mathrm{C}=\mathrm{O}), 1239$ and $1165(\mathrm{C}-\mathrm{O})$.

${ }^{1} \mathrm{H}$ NMR $\left(300.00 \mathrm{MHz}, \mathrm{CDCl}_{3}\right) \delta(\mathrm{ppm}): 2.96\left(\mathrm{~s}, 3 \mathrm{H}, \mathrm{CH}_{3}\right), 2.61$ $\left(\mathrm{s}, 3 \mathrm{H}, \mathrm{CH}_{3}\right), 3.83\left(\mathrm{~s}, 3 \mathrm{H}, \mathrm{Ph}-\mathrm{OCH}_{3}\right), 4.02\left(\mathrm{~s}, 3 \mathrm{H}, \mathrm{OCH}_{3}\right), 6.88$ (d, $2 \mathrm{H}, J=8.9 \mathrm{~Hz}, \mathrm{H}-2^{\prime}$ and $\left.\mathrm{H}-6^{\prime}\right), 7.05\left(\mathrm{~d}, 2 \mathrm{H}, J=8.5 \mathrm{~Hz}, \mathrm{H}-3^{\prime}\right.$ and $\mathrm{H}-5^{\prime}$ ), 7.94 (s, 1H, N-H).

Methyl 6-bromo-7-(4-chlorophenyl)amino-1,3-dimethyl-5,8dioxo-5,8-dihydroisoquinoline-4-carboxylate (10d). The substance 10d was obtained as an orange solid, mp: $140-142{ }^{\circ} \mathrm{C}$, in $62 \%$ yield.

IR $\nu_{\max }\left(\mathrm{cm}^{-1} ; \mathrm{KBr}\right): 3306(\mathrm{~N}-\mathrm{H}), 1732$ and $1677(\mathrm{C}=\mathrm{O}), 1244$ and $1083(\mathrm{C}-\mathrm{O})$.

${ }^{1} \mathrm{H}$ NMR $\left(500.00 \mathrm{MHz}, \mathrm{CDCl}_{3}\right) \delta(\mathrm{ppm}): 2.61\left(\mathrm{~s}, 3 \mathrm{H}, \mathrm{CH}_{3}\right), 2.96$ $\left(\mathrm{s}, 3 \mathrm{H}, \mathrm{CH}_{3}\right), 4.03\left(\mathrm{~s}, 3 \mathrm{H}, \mathrm{OCH}_{3}\right), 7.03\left(\mathrm{~d}, 2 \mathrm{H}, J=8.4 \mathrm{~Hz}, \mathrm{H}-2^{\prime}\right.$ and $\mathrm{H}-6^{\prime}$ ), 7.33 (d, 2H, $J=8.4 \mathrm{~Hz}, \mathrm{H}-3^{\prime}$ and $\left.\mathrm{H}-5^{\prime}\right), 7.89$ (s, $\left.1 \mathrm{H}, \mathrm{N}-\mathrm{H}\right)$.

Methyl 6-bromo-3-bromoethyl-7-(4-methoxyphenyl)amino-1methyl-5,8-dioxo-5,8-dihydroisoquinoline-4-carboxylate (19c). The substance $19 \mathrm{c}$ was obtained as a red solid, mp: $121-123{ }^{\circ} \mathrm{C}$, in $35 \%$ yield.

IR $\nu_{\max }\left(\mathrm{cm}^{-1} ; \mathrm{KBr}\right): 3286(\mathrm{~N}-\mathrm{H}), 1728$ and $1677(\mathrm{C}=\mathrm{O}), 1297$ and $1079(\mathrm{C}-\mathrm{O})$.

${ }^{1} \mathrm{H}$ NMR $\left(500.00 \mathrm{MHz}, \mathrm{CDCl}_{3}\right) \delta(\mathrm{ppm}): 2.98\left(\mathrm{~s}, 3 \mathrm{H}, \mathrm{CH}_{3}\right), 3.83$ (s, $\left.3 \mathrm{H}, \mathrm{Ph}-\mathrm{OCH}_{3}\right), 4.04$ (s, $\left.3 \mathrm{H}, \mathrm{OCH}_{3}\right), 4.55$ (s, $2 \mathrm{H}, \mathrm{C} 3-\mathrm{CH}_{2}-\mathrm{Br}$ ), $6.88\left(\mathrm{~d}, 2 \mathrm{H}, J=8.8 \mathrm{~Hz}, \mathrm{H}-2^{\prime}\right.$ and $\left.\mathrm{H}^{-} 6^{\prime}\right), 7.05(\mathrm{~d}, 2 \mathrm{H}, J=8.8 \mathrm{~Hz}, \mathrm{H}-$ $3^{\prime}$ and $\left.\mathrm{H}-5^{\prime}\right), 7.92(\mathrm{~s}, 1 \mathrm{H}, \mathrm{N}-\mathrm{H})$.

${ }^{13} \mathrm{C} \mathrm{NMR}\left(125.0 \mathrm{MHz}, \mathrm{CDCl}_{3}\right) \delta(\mathrm{ppm}): 25.9\left(\mathrm{CH}_{3}\right), 29.2\left(\mathrm{CH}_{2}\right)$, $53.3\left(\mathrm{OCH}_{3}\right), 55.5\left(\mathrm{Ph}-\mathrm{OCH}_{3}\right), 120.9(\mathrm{C}-8 \mathrm{a}), 113.8\left(\mathrm{C}-2^{\prime}\right.$ and $\left.\mathrm{C}-6^{\prime}\right)$, $125.9(\mathrm{C}-4), 126.9\left(\mathrm{C}-3^{\prime}\right.$ and $\left.\mathrm{C}-5^{\prime}\right), 129.3\left(\mathrm{C}-1^{\prime}\right), 158.3\left(\mathrm{C}-4^{\prime}\right), 138.2$
(C-4a), 103.5 (C-6), 144.9 (C-7), 158.5 (C-3), 161.8 (C-1), 167.3 (C4b), 174.8 (C-5), 179.4 (C-8).

HRMS $[\mathrm{M}+\mathrm{H}]^{+}: \mathrm{m} / z$ calcd for $\mathrm{C}_{20} \mathrm{H}_{16} \mathrm{Br}_{2} \mathrm{~N}_{2} \mathrm{O}_{5}:$ 522.9504; found: 522.9487 .

Methyl 6-bromo-3-bromoethyl-7-(4-chlorophenyl)amino-1methyl-5,8-dioxo-5,8-dihydroisoquinoline-4-carboxylate (19d). The substance 19d was obtained as a red solid, mp: $160-162{ }^{\circ} \mathrm{C}$, in $30 \%$ yield.

IR $\nu_{\max }\left(\mathrm{cm}^{-1} ; \mathrm{KBr}\right): 3295(\mathrm{~N}-\mathrm{H}), 1736$ and $1679(\mathrm{C}=\mathrm{O}), 1300$ and $1092(\mathrm{C}-\mathrm{O})$.

${ }^{1} \mathrm{H}$ NMR (500.00 MHz, $\left.\mathrm{CDCl}_{3}\right) \delta(\mathrm{ppm}): 2.89\left(\mathrm{~s}, 3 \mathrm{H}, \mathrm{CH}_{3}\right), 3.95$ $\left(\mathrm{s}, 3 \mathrm{H}, \mathrm{OCH}_{3}\right), 4.47\left(\mathrm{~s}, 2 \mathrm{H}, \mathrm{C} 3-\mathrm{CH}_{2}-\mathrm{Br}\right), 6.95(\mathrm{~d}, 2 \mathrm{H}, J=8.5 \mathrm{~Hz}$, $\mathrm{H}-2^{\prime}$ and $\left.\mathrm{H}-6^{\prime}\right), 7.24\left(\mathrm{~d}, 2 \mathrm{H}, J=8.7 \mathrm{~Hz}, \mathrm{H}-3^{\prime}\right.$ and $\left.\mathrm{H}-5^{\prime}\right), 7.85(\mathrm{~s}, 1 \mathrm{H}$, $\mathrm{N}-\mathrm{H})$.

${ }^{13} \mathrm{C} \mathrm{NMR}\left(125.0 \mathrm{MHz}, \mathrm{CDCl}_{3}\right) \delta(\mathrm{ppm}): 26.2\left(\mathrm{CH}_{3}\right), 29.5\left(\mathrm{CH}_{2}\right)$, $53.5\left(\mathrm{OCH}_{3}\right), 120.8(\mathrm{C}-8 \mathrm{a}), 126.3\left(\mathrm{C}-2^{\prime}\right.$ and $\left.\mathrm{C}^{\prime}{ }^{\prime}\right), 125.8(\mathrm{C}-4)$, $128.8\left(\mathrm{C}-3^{\prime}\right.$ and ${\mathrm{C}-5^{\prime}}^{\prime}), 132.2\left(\mathrm{C}-4^{\prime}\right), 135.4\left(\mathrm{C}-1^{\prime}\right), 137.9(\mathrm{C}-4 \mathrm{a})$, 105.4 (C-6), 144.8 (C-7), 158.6 (C-3), 162.2 (C-1), 167.4 (C-4b), 175.2 (C-5), 179.4 (C-8).

HRMS $\left(\mathbf{M}^{+}\right): m / z$ calcd for $\mathrm{C}_{19} \mathrm{H}_{13} \mathrm{Br}_{2} \mathrm{~N}_{2} \mathrm{O}_{4}$ : 526.9009; found: 526.9003.

\section{Acknowledgements}

This work was supported by the Brazilian agency FAPERJ. Fellowships granted to UFF, by CAPES, CNPq, CNPq-PIBIC and FAPERJ are gratefully acknowledged.

\section{References}

1 World Health Organization, Resistance Global Report on Surveillance, Geneva, 2014, http:/www.who.int/drugresistance/ documents/surveillancereport/en/, accessed April 2016.

2 I. Roca, M. Akova, F. Baquero, J. Carlet, M. Cavaleri, S. Coenen, J. Cohen, D. Findlay, I. Gyssens, O. E. Heure, G. Kahlmeter, H. Kruse, R. Laxminarayan, E. Liébana, L. López-Cerero, A. MacGowan, M. Martins, J. RodríguezBaño, J. M. Rolain, C. Segovia, B. Sigauque, E. Taconelli, E. Wellington and J. Vila, New Microbes New Infect., 2015, 6, 22-29.

3 Centers for Disease Control and Prevention (CDC), Antibiotic/ Antimicrobial Resistance, https://www.cdc.gov/drugresistance/ , accessed, August 2016.

4 A. P. Magiorakos, A. Srinivasan, R. B. Carey, Y. Carmeli, M. E. Falagas, C. G. Giske, S. Harbarth, J. F. Hindler, G. Kahlmeter, B. Olsson-Liljequist, D. L. Paterson, L. B. Rice, J. Stelling, M. J. Struelens, A. Vatopoulos, J. T. Weber and D. L. Monnet, Clin. Microbiol. Infect., 2012, 18, 268-281.

5 L. J. V. Piddock, Lancet Infect. Dis., 2012, 12, 249-253.

6 E. Ruppé, P. L. Woerther and F. Barbier, Ann. Intensive Care, 2015, 5, 21.

7 C. S. Lee and Y. Doi, Infect. Chemother., 2014, 46, 149-164.

8 X. Li, P. Plésiat and H. Nikaido, Clin. Microbiol. Rev., 2015, 28, 337-418.

9 B. Mehrad, N. M. Clark, G. G. Zhanel and J. P. Lynch, Chest, 2015, 147, 1413-1421. 
10 N. Rabin, Y. Zheng, C. Opoku-Temeng, Y. Du, E. Bonsu and H. O. Sintim, Future Med. Chem., 2015, 5, 647-671.

11 A. Penesyan, M. Gillings and I. T. Paulsen, Molecules, 2015, 20, 5286-5298.

12 S. J. Cole, A. R. Records, M. W. Orr, S. B. Linden and V. T. Lee, Infect. Immun., 2014, 82, 2048-2058.

13 C. Beloin, A. Roux and J. Ghigo, Curr. Top. Microbiol. Immunol., 2008, 322, 249-289.

14 J. G. Malone, Infect. Drug Resist., 2015, 8, 237-247.

15 G. Laverty, S. P. Gorman and B. F. Gilmore, Pathogens, 2014, 3, 596-632.

16 M. Bassetti and E. Righi, Curr. Opin. Crit. Care, 2015, 5, 402411.

17 K. S. Kaye and J. M. Pogue, Pharmacotherapy, 2015, 35, 949962.

18 J. M. Pagès, S. Peslier, T. A. Keating, J. P. Lavigne and W. W. Nichols, Antimicrob. Agents Chemother., 2015, 60, 1349-1359.

19 K. J. Swapnaja, S. Yennam, M. Chavali, Y. Poornachandra, C. G. Kumar, K. Muthusamy, V. B. Jayaraman, P. Arumugam, S. Balasubramanian and K. K. Sriram, Eur. J. Med. Chem., 2016, 117, 85-98.

20 L. Macedo, T. Fernandes, L. Silveira, A. Mesquita, A. A. Franchitti and E. A. Ximenes, Phytomedicine, 2013, 21, 25-29.

21 (a) Y. Kumagai, Y. Shinkai, T. Miura and A. K. Cho, Annu. Rev. Pharmacol. Toxicol., 2012, 52, 221-247; (b) E. Sailaja, S. Bhavani, D. Rambabu, M. V. B. Rao and M. Pal, Curr. Catal., 2014, 3, 310-315; (c) M. N. da Silva, V. F. Ferreira and M. C. B. V. de Souza, Quim. Nova, 2003, 26, 407-416; (d) E. Pérez-Sacau, R. G. Díaz-Penate, A. Estévez-Braun, A. G. Ravelo, J. M. Garcia-Castellano, L. Pardo and M. Campillo, J. Med. Chem., 2007, 50, 696-706.

22 (a) J. Kang, P. Zhang, Z. Gao, J. Zhang, Z. Yan, H. Wang and R. Chen, Phytochemistry, 2016, 130, 144-151; (b) V. R. Campos, W. A. Silva, V. F. Ferreira, C. S. Souza, P. D. Fernandes, V. N. Moreira, D. R. Rocha, F. R. F. Dias, R. C. Montenegro, M. C. B. V. Souza, F. C. S. Boechat, C. F. J. Franco, J. A. L. C. Resende and A. C. Cunha, RSC $A d v .$, 2015, 5, 96222-96229; (c) V. R. Campos, E. A. Santos, V. F. Ferreira, R. C. Montenegro, M. C. B. V. Souza, L. V. Costa-Lotufo, M. O. Moraes, A. K. P. Regufe, A. K. Jordão, A. C. Pinto, J. A. L. C. Resende and A. C. Cunha, RSC Adv., 2012, 2, 11438-11448.

23 P. Ravichandiran, D. Premnath and S. Vasanthkumar, J. Biol. Chem., 2014, 7, 93-101.

24 M. A. Castro, A. M. Gamito, V. Tangarife-Castaño, B. Zapata, J. M. Miguel del Corral, A. C. Mesa-Arango, L. BetancurGalvis and A. San Feliciano, Eur. J. Med. Chem., 2013, 67, 19-27.

25 I. T. Crosby, D. G. Bourke, E. D. Jones, P. J. de Bruyn, D. Rhodes, N. Vandegraaff, S. Cox, J. A. V. Coates and A. D. Robertson, Bioorg. Med. Chem., 2010, 18, 6442-6450.

26 E. M. Malik and C. E. Müller, Med. Res. Rev., 2016, 36, 705748.

27 P. F. Carneiro, M. C. Pinto, R. K. Marra, F. C da Silva, J. A. Resende, E. S. L. F. Rocha, H. G. Alves, G. S. Barbosa,
M. C. de Vasconcellos, E. S. Lima, A. M. Pohlit and V. F. Ferreira, Eur. J. Med. Chem., 2016, 108, 134-140.

28 (a) X. Zhang, H. Y. Xu, A. M. Huang, L. Wang, Q. Wang, P. Y. Cao and P. M. Yang, Chem. Pharm. Bull., 2016, 64, 1036-1042; (b) D. Schulz, P. Beese, B. Ohlendorf, A. Erhard, H. Zinecker, C. Dorador and J. F. Imhoff, J. Antibiot., 2011, 64, 763-768; (c) A. K. Jordão, J. Novais, B. Leal, A. C. Escobar, H. M. dos Santos Jr, H. C. Castro and V. F. Ferreira, Eur. J. Med. Chem., 2013, 63, 196-201.

29 (a) P. Ravichandiran, A. Jegan, D. Premnath, V. S. Periasamy, S. Muthusubramanian and S. Vasanthkumar, Bioorg. Chem., 2014, 53, 24-36; (b) J. A. Mohammed, J. H. Ahmed and H. A. Al-Hazam, Res. J. Pharm., Biol. Chem. Sci., 2014, 5, 1328-1339; (c) S. A. A. Osman, A. A. Abdalla and M. O. Alaib, J. Pharm. Sci., 1983, 72, 68-71.

30 (a) V. K. Tandon, H. K. Maurya, N. N. Mishra and P. K. Shukla, Eur. J. Med. Chem., 2009, 44, 3130-3137; (b) C. Ryu and D. Kim, Arch. Pharmacal Res., 1992, 15, 263-268.

31 R. S. Medina, M. P. Barros, R. S. Galhardo, L. E. S. Netto, P. Colepicolo and C. F. M. Menck, Res. Microbiol., 2006, 157, 275-281.

32 S. Karkare, T. T. H. Chung, F. Collin, L. A. Mitchenall, A. R. McKay, S. J. Greive, J. J. M. Meyer, N. Lall and A. Maxwell, J. Biol. Chem., 2013, 288, 5149-5156.

33 M. Jeya, H. J. Moon, J. L. Lee, I. W. Kim and J. K. Lee, Appl. Microbiol. Biotechnol., 2010, 85, 1653-1663.

34 C. Ryu, A. L. Song and J. A. Hong, Bioorg. Med. Chem. Lett., 2013, 23, 2065-2068.

35 J. A. Barnett, Yeast, 2003, 12, 1015-1044.

36 J. A. Valderrama, J. A. Ibacache, V. Arancibia, J. Rodriguez and C. Theoduloz, Bioorg. Med. Chem., 2009, 17, 2894-2901.

37 A. Marella, O. P. Tanwar, R. Saha, M. R. Ali, S. Srivastava, M. Akhter, M. Shaquiquzzaman and M. M. Alam, Saudi Pharm. J., 2013, 21, 1-12.

38 X. J. Fang, P. Jeyakkumar, S. R. Avula, Q. Zhou and C. H. Zhou, Bioorg. Med. Chem. Lett., 2016, 26, 2584-2588.

39 K. Konaté, J. F. Mavoungou, A. N. Lepengué, R. R. R. A. Samseny, A. Hilou, A. Souza, M. H. Dicko and B. M'Batchi, Ann. Clin. Microbiol. Antimicrob., 2012, 11, 18.

40 L. Martínez-Martínez and J. Calvo, Enfermedades Infecciosas y Microbiologia Clinica, 2010, 28, 25-31.

41 F. Silva, O. Lourenço, J. A. Queiroz and F. C. Domingues, J. Antibiot., 2011, 64, 321-325.

42 D. Fisher, Y. Li, B. Ahlemeyer, J. Krieglstein and T. Kissel, Biomaterials, 2003, 24, 1121-1131.

43 J. B. Baell, Future Med. Chem., 2010, 10, 1529-1546.

44 R. F. Bruns and I. A. Watson, J. Med. Chem., 2012, 55, 97639772.

$45 \mathrm{~J}$. Baell and M. A. Walters, Nature, 2014, 513, 481-483.

46 World Health Organization, Antimicrobial resistance, http:// www.who.int/mediacentre/factsheets/fs194/en/, accessed, February 2016.

47 C. Ibis, A. F. Tuyun, Z. Ozsoy-Gunes, H. Bahar, M. V. Stasevych, R. Y. Musyanovych, O. Komarovska-Porokhnyavets and V. Novikov, Eur. J. Med. Chem., 2011, 46, 5861-5867.

48 G. Alebachew, B. Teka, M. Endris, Y. Shiferaw and B. Tessema, BioMed Res. Int., 2016, 1-8. 
49 CLSI, Clinical and Laboratory Standard Institute.M100-S25 Performance Standards for Antimicrobial Susceptibility Testing, Twenty-fifth Informational Supplement 35 (3): 1240, 2015.

50 E. L. Chuah, Z. A. Zakaria, Z. Suhaili, S. Abu Bakar and M. N. Desa, J. Microbiol. Res., 2014, 4, 6-13.

51 K. Konaté, P. Zerbo, M. Ouédraogo, C. I. Dibala, H. Adama, O. Sytar, M. Brestic, N. Barro, G. A. Pankey and L. D. Sabath, Ann. Clin. Microbiol. Antimicrob., 2013, 12-14.
52 P. C. Sathler, A. L. Lourenço, C. R. Rodrigues, L. C. da Silva, L. M. Cabral, A. K. Jordão, A. C. Cunha, M. C. Vieira, V. F. Ferreira, C. E. Carvalho-Pinto, H. C. Kang and H. C. Castro, Thromb. Res., 2014, 134, 376-383.

53 M. J. Parnham and H. Wetzig, Chem. Phys. Lipids, 1993, 64, 263-274.

54 M. Bauer, C. Lautenschlaeger, K. Kempe, L. Tauhardt, U. S. Schubert and D. Fischer, Macromol. Biosci., 2012, 7, 986-998. 